\title{
Exploring Biopower in the Regulation of Farm Animal Bodies: Genetic Policy Interventions in UK Livestock
}

\author{
LEWIS HOLLOWAY \& CAROL MORRIS ${ }^{1}$
}

\begin{abstract}
This paper explores the analytical relevance of Foucault's notion of biopower in the context of regulating and managing non-human lives and populations, specifically those animals that are the focus of livestock breeding based on genetic techniques. The concept of biopower is seen as offering theoretical possibilities precisely because it is concerned with the regulation of life and of populations. The paper approaches the task of testing the 'analytic mettle' of biopower through an analysis of four policy documents concerned with farm animal genetics: the UK's National Scrapie Plan (2003); the UK National Action Plan on Farm Animal Genetic Resources (2006); the Agriculture and Environment Biotechnology Committee's report on Animals and Biotechnology (2002); and the Farm Animal Welfare Council's report on the Welfare Implications of Animal Breeding and Breeding Technologies in Commercial Agriculture (2004). Of interest is whether and how the four policy case studies articulate a form of biopower in relation to human-livestock animal relations in the context of genetic approaches to livestock breeding, and how biopower is variably expressed in relation to the different policy issues addressed. In concluding, the paper considers the overall applicability and relevance of biopower in the context of regulating animal lives within livestock breeding, highlighting both possibilities and limitations, and offers suggestions for taking forward research on livestock populations from a neo-Foucaultian perspective.
\end{abstract}

\section{Introduction}

Genetic techniques ${ }^{2}$ became increasingly important in livestock breeding during the second half of the twentieth century. They include statistical calculations of animals' 'genetic merit', identification of marker genes associated with particular qualities such as enhanced productivity or reduced disease susceptibility, and the possibilities of creating genetically modified livestock. ${ }^{3}$ Such is the significance of these developments that they have been labelled a 'genetics revolution' by the scientists involved. ${ }^{4}$ Livestock breeding has long been the subject of scientific interventions of various kinds, concerning selective breeding, nutrition and health. However, genetic techniques represent a more fundamental intervention in the lives of agricultural animals, based on the notion of genes and genomes, phenomena that are partly embodied within individual animals and identification of which has other implications for the bodies of these animals. Indeed, these techniques suggest that the lives of animals, as individuals and as populations, are being understood, regulated and managed in new and complex ways, a process that demands examination. ${ }^{5}$ One means of approaching this task is through Foucault's notion of 'biopower' ${ }^{6}$ which offers theoretical possibilities precisely because it is concerned with the regulation of life and of populations. However, because this concept was developed in relation to human lives and populations its legitimacy needs to be established in the non-human 
context. The overall objective of this paper, therefore, is to test the 'analytic mettle" of biopower in the context of livestock agriculture and specifically the breeding of livestock through genetic interventions.

We do this through an analysis of policy issues which engage with farm animal genetics, an engagement which has increased in recent years in parallel with the development of genetic breeding techniques. Four specific policy documents have been selected as a vehicle for our exploration of the relevance of biopower in understanding the regulation of agricultural animal lives. The first of these is the UK's National Scrapie Plan (NSP), ${ }^{8}$ which has, since 2001, used genomic testing as the basis for attempts to eradicate scrapie from the UK national sheep flock, while the second, the UK National Action Plan on Farm Animal Genetic Resources (FAnGR), ${ }^{9}$ establishes a strategy for conserving UK livestock biodiversity. Both represent significant policy developments: the NSP is the only policy initiative to date that has actually deployed genomic testing in the national level management of the sheep population, while FAnGR is a national response to an international policy drive founded on the use of genetic knowledge in the quest for biodiversity conservation. The third policy document is the Agriculture and Environment Biotechnology Committee's (AEBC) report on Animals and Biotechnology, ${ }^{10}$ which examined the regulatory implications of biotechnological developments for agriculture and the environment, and the fourth, the Farm Animal Welfare Council's (FAWC) report on the Welfare Implications of Animal Breeding and Breeding Technologies in Commercial Agriculture, ${ }^{11}$ includes discussion of genetic methods in breeding stock. Again, both reports are significant as they have been produced by independent organisations appointed to provide strategic advice to the UK government on the regulation of agricultural biotechnology and all aspects of farm animal welfare respectively. Although other policy-informing reports on agricultural biotechnology and its regulation have been published over the last decade, the two selected for analysis here represent the most recent statements that deal with the issue and, in the case of the FAWC report, build from and bring together the findings from earlier reports. $^{12}$

We begin by outlining Foucault's conception of biopower and how this has been usefully reworked as the basis of further empirical enquiry by two Foucaultian scholars, Paul Rabinow and Nicolas Rose. ${ }^{13}$ Discussion follows of several issues relating to the use of biopower for making theoretical sense of the regulation and management of non-human populations. The paper next explores the four policy case studies in more detail, outlining their scope and purpose and then examining them through Rabinow and Rose's reconceptualisation of biopower. Of interest is whether and how the four policy case studies articulate a form of biopower in relation to human-livestock animal relations, and how the expression of biopower is different in relation to the different policy issues addressed. Finally, we consider the overall applicability and relevance of biopower (as reformulated by Rabinow and Rose) in the context of regulating animal lives within livestock breeding, highlighting both possibilities and limitations, and offer suggestions for developing research on livestock populations from a neo-Foucaultian perspective. 


\section{Policies, power and biopower}

Foucault's notion of biopower represents an important theorization of power as this relates to (human) life. ${ }^{14}$ All of the policies outlined above are concerned with the lives of farm animals - increasingly defined in terms of their genetic content - and how these lives should be regulated and managed. It is the regulation of life that concerned Foucault who used the general term biopower to describe forms of power focused upon the vital characteristics and capacities of human bodies and the conduct of individuals and collectivities. ${ }^{15}$ For Foucault biopower centred "on the body as a machine: its disciplining, the optimisation of its capabilities, the extortion of its forces, the parallel increase of its usefulness and its docility, its integration into systems of efficient and economic controls..." 16 Within the field of biopower, Foucault distinguished between two forms of 'biopolitics'. The first, 'anatomopolitics', referred to "the disciplinary techniques that sought to maximize the body's forces and integrate it into efficient systems, such as through proper training, or through rationally organizing workplaces, armies and domestic economies". ${ }^{17}$ Biopolitics is the term used to describe the second form and refers to specific political mechanisms, strategies and technologies that take as their object "the biological existence of the nation... understood as a 'population' imbued with the mechanisms of life and knowable in statistical norms". ${ }^{18}$ 'Population' is the key word here since this notion had a very different meaning prior to the eighteenth century. From this time, however, population becomes "the ultimate aim of government". 19

For Foucault, therefore, the emergence of biopower was historically contingent and closely tied up with nation states as these emerged in post-Renaissance Europe. Biopower came to overlay, but not completely replace, the previously dominant mode of 'sovereign power', the power to "curtail life in periodic, spectacular manner". ${ }^{20} \mathrm{In}$ contrast, biopower represented a more "dispersed form of disciplinary or 'pastoral' power ... [the] power to make live or let die". ${ }^{21}$ The reason for this shift in the operation and form of power, so Legg suggests, was tied up with decline of feudalism and, more specifically, the establishment of the agricultural and industrial revolutions, both of which led to a mass movement of people into cities and the subsequent need for their 'management'. ${ }^{22}$ Furthermore, the emergence of competitive nation states required healthy and well-disciplined 'populations' to ensure their survival ${ }^{23}$ Foucault envisaged the human sciences, together with a set of administrative institutions associated with the nation state, as central to the production and operation of biopower during the eighteenth and nineteenth centuries. Policy interventions in the birth rate and morbidity, and measures to coordinate medical care were the primary focus of biopower.

In spite of the formulation of biopower in relation to a particular historical period and set of phenomena associated with that period, the notion of biopower clearly has resonance and analytical potential in understanding the operation and distribution of power in contemporary society. Indeed, Marks claims that biopolitical processes are part of the fabric of everyday reality in advanced capitalist economies. ${ }^{24}$ A more cautious approach is suggested by Rabinow and Rose, who dispute the notion of an "omnipotent and all-pervasive" biopower, suggesting that while some applications of Foucault's ideas on biopower and biopolitics have many merits they also "entail 
highly general philosophical deployments of the terms which are totalizing and misleading". ${ }^{25}$ They also argue that Foucault himself made limited reference to biopower and so the concept "remains insufficiently developed" and has yet to demonstrate its "analytic mettle in sufficient cases". ${ }^{26}$ In an attempt to provide further conceptual clarity Rabinow and Rose suggest that the concept of biopower must, at a minimum, include three elements. The first is "one or more truth discourses about the 'vital' character of living human beings, and an array of authorities considered competent to speak that truth". ${ }^{27}$ Truth discourses can have their origins in a number of disciplines, including the biological and the sociological. The second is strategies for intervention upon collective existence in the name of life and health. These strategies are directed at populations often, although not necessarily, identified at the scale of the nation state, and "emergent biosocial collectivities" 28 such as those based on race or gender. The third element is 'modes of subjectification', which refers to the means by which individuals come to regulate themselves and their own sense of self and body in relation to truth discourses. In any particular instance of biopower, it is important to understand that it is not that one or other of the three elements is dominant, causing or producing the others as effects. Instead, truth discourses, strategies for intervention and subjectivities are co-constitutive and co-emergent within relations of biopower. The three elements of biopower and the way in which these are co-constituted in diverse ways require further "detailed, empirically grounded enquiry", according to Rabinow and Rose, ${ }^{29}$ for example in examining the ways in which, in particular instances, intervention strategies might be seen as attempts to realise the ideas for collective existence immanent in particular truth discourses, or in exploring how emergent truth discourses might be used to legitimise particular forms of intervention.

Policy developments relating to genetic approaches to livestock breeding offer one potential empirical context to further test the 'analytic mettle' of biopower. As Marks observes "the conceptual resources of thinking on biopolitics have been seen by many as a useful and analytical tool for looking in particular at the ways in which the postwar development of molecular biology has provided new pathways for politics to penetrate the material components of life" ${ }^{30}$ He goes on to argue that many recent biotechnological issues such as gene therapy and the human genome project all raise significant biopolitical issues. Also relevant is research that explores the operation of biopower through policy developments, both contemporary and historical. For example, Legg utilises an analytical scheme derived from the Foucaultian literature on governmentality (the conceptualization of which is bound up with the related notions of biopolitics, population and discipline) to examine three reports that dealt with Delhi's congestion problem in the colonial period. ${ }^{31}$ In a contemporary context Gilbert examines a recent political document (the Security and Prosperity Partnership) drawn up in 2005 by the US, Canadian and Mexican governments in an attempt to redefine the nature of cross-border relationships. ${ }^{32}$ Reading this document through the lens of the Foucaultian governmentality literature, Gilbert finds evidence of a biopolitical rationality that refocuses political attention on the needs and wants of the 'citizen' and away from the management of the 'population'.

Reading policies through a Foucaultian lens, therefore, has some useful precedents that legitimise and inform the analysis herein. But before we undertake this task we 
need to consider the implications of utilising what is essentially an anthropocentric theory of power within the context of animal lives and populations.

\section{Biopower and animals}

Limited efforts have been made to apply Foucault's ideas to the study of animals and human-animal relations, and within this already small body of work the specific area of biopower has received very little attention. In relation to Foucault's wider theorisation of power, for example, some attention has been paid to conceptions of disciplinary power in human-animal relationships. Novek, for instance, explores this in relation to intensive forms of livestock husbandry, and Williams explores how the recognition of animal sentience is used to deepen the disciplining of animals in and around meatpacking plants in order to elicit particular behaviours useful to the plant management. Work by Palmer and Holloway, in contrast, examines Foucault's understanding that disciplinary power is not simply repressive, but is a productive phenomenon within human-animal relationships, associated for instance with the emergence of particular sorts of human and animal subjectivity. ${ }^{33}$ Holloway also discusses biopower as a useful concept in exploring human-animal relationships which involve the active intervention by people in the lives and bodies of livestock animals in contemporary agriculture; here, he examines the operation of biopower in relation to the deployment of robotic and information technologies in dairy farming. In this context, Holloway, drawing on Rabinow and Rose's three elements of biopower which we drew attention to above, acknowledges that there are problems associated with applying these to animals. Here, we consider these problems in a little more detail, suggesting that they need to be borne in mind in assessing the concept of biopower in examinations of human-animal relationships in general, and genetic policy interventions in livestock agriculture in particular.

First, the extent to which human-animal relationships exemplify biopower rather than 'sovereign' (or indeed some other mode of) power needs consideration. Above, we outlined Foucault's description of a biopower which came to overlie sovereign power in post-Renaissance Europe. The particular form of power exemplified by sovereign power is the power to curtail life, and clearly in relation to livestock animals the power to closely confine, control and end the lives of the animals concerned is strongly evident. However, the ways in which this power is expressed in livestock agriculture is in some important ways different to the expression of sovereign power as described by Foucault in relation to human populations. First, power over the life of livestock is, at least in contemporary Western contexts, particularly mundane, in contrast to the spectacular events periodically associated with the exercise of sovereign power over the life of humans. The slaughter of thousands of animals is daily routine in livestock systems which have effectively objectified animals, and far from acts of slaughter being public events, most in the West have become progressively distanced from the farming and killing of the animals they eventually consume, although spectacular and very public events such as the mass slaughter of animals resulting from the 2001 outbreak of Foot and Mouth Disease in the UK served as a reminder of the deaths of animals which underpin meat-based diets. ${ }^{34}$ Second, alongside the power over life exemplified by the act of slaughter, the exercising of human power over the life of livestock animals has proceeded in other, 
more subtle ways, through processes of domestication, selective breeding, and, increasingly, the application of genetic knowledge-practices. ${ }^{35}$ These interventions represent attempts to direct and regulate life, to integrate that life into the technologies and economics of what have become industrialised agricultural systems. As such, overlying the powerful relations of domination which unarguably subtend contemporary livestock agriculture is a set of relations which, we argue, constitute a form of biopower operating between humans and livestock animals.

This argument that biopower is relevant in considering human-livestock animal relations raises two further issues. First, for Foucault, the notion of biopower was constituted in relation to an idea of population - an idea that took on particular meanings from the late $18^{\text {th }}$ Century, and in particular was associated with the idea of the nation state. With regard to livestock, there is perhaps a number of different 'populations' at different scales, which might be considered the subject of relations of biopower. These include, for instance, the 'national herds/flocks' of the different species of livestock animal, but also a herd or flock on an individual farm. Further types of population are the different breeds of livestock within a national territory, or even international populations of animals related through their common membership of a breed. ${ }^{36}$ In some ways, the differentiated effects of biopower in relation to how different groupings are defined parallel the way that Rabinow and Rose argue that categories of race or gender have formed the basis for different sorts of interventions in human populations. In assessing biopower in relation to policy interventions, it is clear that an understanding of how they constitute particular notions of population is necessary. The terminology of 'biosocial collectivities' adopted by Rabinow and Rose is particularly valuable here, allowing a move beyond the limitations of geographically proximate populations of the same species (ie, humans), to take into account non-proximate and heterogeneous groupings which might be constituted by members of different species (both human and nonhuman).

Second, Foucault's biopower was, as concerned with national populations and the nation state, necessarily connected to state-level interest and interventions in populations. Yet, as Rabinow and Rose imply, from the later part of the $20^{\text {th }}$ century, strategies for interventions have involved an array of state, quasi-state and non-state institutions, particularly in relation to genetic truth discourses. Similarly, in relation to livestock, a network of different types of institution can be understood as implicated in the formulation and implementation of strategies for intervening in the collective existence of livestock populations. Such institutions include those of the state (such as the relevant government departments), those sponsored by the state (such as government-funded agricultural research institutes), as well as private sector organisations (eg, commercial breeding companies) and the voluntary sector (eg, UK breed societies ${ }^{37}$ ). Here then, in relation to livestock breeding, biopower is distributed across networks of related institutions, including at the micro-scale the individual breeding unit or farm at which many interventions in farm-scale populations are conducted, and is related to the particular forms of institutionalisation which have come to characterise livestock breeding from the late $20^{\text {th }}$ Century. 


\section{Policy interventions in the life of livestock animals}

To further examine the issues raised above, we return now to our four case studies. Although all are concerned with genetic approaches to livestock breeding, they represent two distinct types of policy intervention. The first (NSP and FAnGR) surrounds concerns relating to, for example, specific animal health, disease and welfare issues, and ecological notions of biodiversity. Here, intervention has increasingly been articulated through an understanding that it is the genetic characteristics of livestock populations which should be the focus of attention, and specific policies and consultation documents have, to a greater or lesser degree, been formulated around a sense that livestock genetics can be managed in order to achieve desirable outcomes. The second type of intervention (the AEBC and FAWC reports) has emerged, somewhat ironically, in response to concerns about the effects of an increasing 'geneticisation, 38 of livestock breeding practices. In this case, policyinfluencing activity has centred around debates about the extent to which policy intervention is required in order to mitigate some of the potentially negative implications of regarding livestock increasingly as the products or bearers of genetic material. The first type of policy intervention can be understood as promoting opportunities arising from the potential insights into livestock provided by genetic/genomic science, while the second form seeks to address (through regulatory changes) the potential threats associated with biotechnological and other developments in livestock breeding.

After outlining the four policy interventions, we focus in particular on the ways in which they articulate a form of biopower, as theorised by Rabinow and Rose, in operation in relation to livestock, and explore how biopower is expressed differently in relation to the different issues addressed in these interventions.

\section{National Scrapie Plan}

Scrapie is a Transmissible Spongiform Encephalopathy, fatal to sheep. Concerns that the presence of scrapie in sheep might mask the presence of BSE in such animals, with consequent health implications for humans who consume infected sheepmeat, led to the establishment of the NSP, which aimed to eradicate scrapie from the national flock through a Ram Genotyping Scheme. The NSP is underpinned by claims that 'conventional' methods of disease control, "traditionally based on the diagnosis of infected animals and the prevention of transmission to other stock" cannot be applied in the case of scrapie. ${ }^{39}$ The NSP's strategy for intervention is instead predicated on a genetic understanding of the relationship between livestock animals and the disease. Key to the NSP is the fact that sheep with different genotypes are more or less susceptible to scrapie. The NSP thus centres on the identification of marker genes from sheep blood samples, a testing process referred to as Prion Protein (PrP) Genotyping, which allocates sheep to one of five categories (their PrP Genotype): the strategy thus focuses on retaining as breeding stock those animals which are theoretically genetically more resistant to scrapie, and culling those which are more susceptible. Initially a voluntary scheme, as a result of EU legislation, the NSP developed into a compulsory programme in 2004 for those flocks which experienced 
a case of scrapie, and in 2006 it focused on pedigree flocks and other flocks breeding rams to be used in breeding. ${ }^{40}$

\section{Farm Animal Genetic Resources}

The second case study is the recent UK National Action Plan on FAnGR. The Action Plan, published by the UK's Department for Environment, Food and Rural Affairs, ${ }^{41}$ was prepared by the National Steering Committee for FAnGR, an advisory committee consisting of scientists and expert representatives of a range of other organisations, which was established in 2004 by the UK government as part of its official response to the UN Food and Agriculture Organisation's global strategy for the protection of the world's animal genetic resources, ${ }^{42}$ a product of the Convention on Biological Diversity drawn up at Rio de Janeiro in 1992. The plan identifies 38 Recommended Actions, together constituting its strategy for conserving farm animal genetic resources. Several are particularly relevant here. Two call for greater levels of 'scientific' and 'molecular' characterisation of livestock breeds. Two others directly relate to concerns about the narrowing of genetic diversity potentially associated with new genetic techniques of livestock breeding (including, specifically, the NSP), while a fifth raises concerns about the potential effects of such techniques on the health and welfare of animals, relating this to the FAWC report, returned to below.

\section{Agriculture and Environment Biotechnology Committee}

The Biotechnology Commission (AEBC) was established in June 2000 with a remit to provide the UK Government and Devolved Administrations with independent, strategic advice on developments in biotechnology and their implications for agriculture and the environment. A sub-group was constituted to produce a report on Animals and Biotechnology (published in $2002^{43}$ ) which considered whether current and future developments in animal biotechnology could be addressed through the existing regulatory and advisory machinery. Adopting a deliberately open and consultative approach to its work, the Commission held a series of meetings with experts and the general public and commissioned two research studies into public attitudes to biotechnology with animals. Its report refers to and builds on earlier publications dealing with animal biotechnology. ${ }^{44}$ Drawing attention to both the positive and negative potentialities of the application of genetic biotechnology to animals, the AEBC comes to the view that "the practical differences between genetic biotechnology and conventional practices are not such as to suggest that GM or cloned animals should be governed separately in every aspect from conventional animals in the regulatory system". "However, it does recognise that GM and cloned animals present a number of potential problems that are not currently addressed in the regulatory system: eg, adequate monitoring of the long term stability and welfare of cloned and GM farm animals if and when they enter conventional production, ensuring consumer choice, and preventing any adverse environmental impacts. As such, it presents a set of seven recommendations for overcoming existing regulatory shortcomings, key among which is a new, independent and strategic advisory body "to examine issues raised by the use of genetic biotechnology on farm animals in the context of its use on other animals and current livestock farming practices". ${ }^{46}$ 


\section{The Farm Animal Welfare Council}

FAWC has, since 1979, provided independent advice to the UK Government on the welfare, and associated legislation, of agricultural animals on farm, in transit and at the place of slaughter. The Council comprises animal and agricultural scientists, economists, representatives of animal breeding companies, veterinary surgeons, farmers, and representatives of consumer interests. Its 2004 report on the welfare implications of animal breeding and breeding technologies in commercial agriculture aimed "to provide clear and practical advice to Government on the establishment of an appropriate framework within which developments in animal breeding and breeding technologies, and the outcome of such processes, may be considered". ${ }^{47}$ The report identifies a number of shortcomings in existing legislation and other (eg, private sector) initiatives relating to animal welfare in the UK, and makes recommendations to address them, key among which is the creation of a Standing Committee to consider animal breeding in agriculture and its welfare consequences. Among its proposed roles the new Committee was expected to oversee a significantly increased level of surveillance of the welfare consequences of current breeding strategies and new breeding technologies, an activity requiring the collection and analysis of existing as well as new data from a variety of sources. The Government subsequently rejected the formation of the new Committee on the grounds of cost, a lack of a clear role for it in the absence of statutory powers, its threat to innovation and trade, and the global nature of animal breeding, which makes a UK-specific body largely redundant. ${ }^{48}$ Instead, the Government sees FAWC itself as well placed to tackle many of the concerns raised and proposes a number of roles it might perform in relation to breeding including building good relationships with UK breeding companies and advising on a code of good practice for these companies (ie, an advisory and voluntary approach to regulation). By and large the Government views existing legislation as sufficient to protect animal welfare in relation to breeding and breeding technologies but it partially agrees with FAWC's call for enhanced surveillance, albeit with emphasis on a voluntary approach to data collection.

\section{'Truth', authority and interventions in the life of livestock animals}

Having outlined our four policy issues, we return now to Rabinow and Rose's three elements of biopower: the existence of truth discourses about the essence of life; strategies for intervention in the collective existence of living beings; and processes of subjectification which produce self-regulating individuals. Here, we focus on the first and second elements, returning to the third in the concluding section.

In all four policy documents, truth discourses about life are fundamental to the development of strategic interventions in the life of livestock animals. In all four cases, a genetic understanding of life is accepted; animal life is regarded as essentially genetically manipulable. For instance, the NSP states that "Studies of the genetics of sheep have ... shown that it is possible to identify whether sheep are resistant or susceptible ...", 49 and FAWC argues that "genotype associated welfare problems are recognised". ${ }^{50}$ Genetic truth discourses thus run through all of the documents, but are articulated in different ways and are related in different ways to other simultaneous 'truths'. This suggests that different modes, or particular types, of biopower can be 
identified in different instances, in relation to the very different issues addressed by the various policy documents. Different modes are thus related to particular combinations of, or relationships between, the different 'truths' associated with them.

In the NSP, the 'life' of sheep is reduced to a genetically-dependent susceptibility to scrapie, so that it is solely the PrP Genotype which is the focus of policy intervention. It is allied, however, with arguments that, first, scrapie poses a threat to human health; second, that as such, it should be 'eradicated'; and third, that genetics is the key to disease susceptibility in this case and that genetic testing is thus the key to eradication. Genetics here thus provides the opportunity of addressing a perceived animal and human health issue. In the case of FAnGR, there is a similar understanding that livestock animals can be 'known' through molecular characterisation. These 'truths' are here allied to, first, an argument that livestock 'biodiversity' should be conserved, and second, an understanding that genetic biodiversity stands alongside other measurements of livestock biodiversity (especially the diversity of livestock breeds) as an appropriate target for policy. As with scrapie, a knowledge of livestock genetics relates to a possible mode of intervention, yet in this case regarding the conservation of genetic diversity, in contrast to the narrowing of diversity which is a possible outcome of attempts to eradicate scrapie.

The other two policy documents address some of the potential consequences of genetic techniques in agriculture, although in common with the first two there is an assumption that such techniques will become increasingly prevalent in livestock breeding. Both the AEBC and FAWC reports draw on different understandings of the essence of life; in particular scientific truths relating to a genetic basis for life become entangled with other truths drawn from moral philosophy which, first, accept an essentially instrumentalist or utilitarian perspective on human relations with animals, but, second, represent animals as sentient beings with their own integrity or 'nature', such that animal lives need to be protected from the possible excesses of human intervention.

These emergent truths about the life of livestock animals gain legitimacy in the current policy context through the recognised expertise of the constituent members of the committees they are associated with, and by their intertextual relations with other reports (including each other) and institutions. In particular, authority is constructed and reproduced within the four cases by a common reference to scientific authority and expertise, used to legitimise the suggested policy interventions in the life of livestock. The NSP, for example, states that "The use of genetics to tackle scrapie has been recommended by the Spongiform Encephalopathy Committee (SEAC), the EU Commission's Scientific Steering Committee and has been endorsed by the Food Standards Agency". ${ }^{51}$ The committees and agency referred to are seen as competent authorities as they too embody scientific expertise. Similarly, FAnGR is chaired by a leading agricultural scientist, with committee members drawn from a range of scientific institutions alongside those with specialised commercial and agricultural knowledge of particular species. Authority in this case is also constructed by reference to the internationally recognised authority of the FAO. In the cases of the AEBC and FAWC, their constitutional concerns with ethical issues associated with genetic interventions in the life of livestock require that alongside scientific expertise, 
authority is simultaneously drawn from other fields. The AEBC is, for example, informed by various scientific disciplines, but at the same time it includes the perspectives and authorities of law and moral philosophy, while FAWC asserts that it "takes account of scientific knowledge and the practical experience of those involved in the agriculture industry ... [and takes] a broad-ranging approach, taking into account all relevant views". 52 Collectively, then, and using Rabinow and Rose's terminology, the policy reports drawn on here can be seen as representing an interlinked array of authorities considered competent to speak truths about the life of livestock animals and the appropriateness of particular types of intervention in that life. Our point here is that although these authorities may in some ways contradict each other, and become allied in different ways to other, sometimes also competing, truth discourses, in specific contexts and at particular moments they are regarded as authoritative, and as such, are associated with effects such as policy responses and changes in the practices of animal agriculture.

A clear strategy for intervention is demonstrated in both the NSP and FAnGR although the strategy and its associated intervention is much more targeted in the case of the NSP where the eradication of a disease represents a singular and very clear aim to be realised through genetic testing. In contrast, the strategy identified by FAnGR is relatively broad in scope - the conservation of the UK's farm animal genetic resources - and relies on genetic interventions (scientific and molecular characterisation) alongside a range of other actions to realise its objective, including the establishment of institutions and reporting structures, the establishment of inventories and recording systems to improve data collection and accessibility, and strategies for genetic conservation. Meanwhile, the strategy for intervention that is called for by the AEBC and FAWC reports is the regulation of agricultural biotechnology and breeding technologies respectively. The strategy here is, primarily, to protect farm animals from the excesses of biotechnological and other breeding developments with the recommended intervention an extension and deepening of livestock governance. While the AEBC calls for the establishment of a new statutory advisory body and FAWC recommends a new Standing Committee, both advocate increased monitoring and surveillance (also endorsed by FAnGR) at a number of scales: individual animal bodies subject to breeding strategies; and the nation state, where flows of genetic material and genetically modified animals (may) cross national borders. The AEBC, informed by a wider constituency of interests, also calls for further means of extending public engagement in decisions about genetic biotechnology, and arranging the means to maintain consumer choice about whether to purchase GM products. All of these recommendations imply the devising of new, or the revision of existing, policy and regulatory instruments relating to the management of livestock populations.

The strategies in all four policies call for intervention in the lives of farm animals both to protect those lives (eg, from disease, loss of genetic diversity, and the welfare consequences of breeding technologies), and also to guarantee the interests of associated human populations (eg, through sustaining the livelihoods of sheep farmers and the health of consumers (in the case of the NSP) and ensuring consumer choice when and if genetically modified animal products are made available commercially, in the case of the AEBC's report). In this way they can be seen to be intervening in, 
and attempting to manage, simultaneously the lives of animal and human populations whose interests are inextricably intertwined.

There are multiple populations at which the strategies for intervention are targeted. Two relatively tightly defined populations, at different geographical scales, are the focus of the NSP: the national sheep flock (a population which should be free of scrapie) and the individual farm flock as the population where intervention through genetic testing, culling etc. occurs. Cutting across both of these populations is another - breed - with some breeds identified as being less susceptible to scrapie than others and therefore of increased economic interest. The populations that are the focus of intervention within FAnGR are somewhat more loosely defined. Population here is, in one sense, all livestock in the UK, but differentiated according to species, breed and 'strains' within breeds. Alongside these populations 'biosocial collectivities' provide an additional focus for the strategies for intervention. Such a notion evokes assemblages comprising both human and non-human entities. In the case of the NSP, therefore, the targeted biosocial collective comprises sheep (as individuals), genetic material, individual humans including farmers and breeders, disease vectors and a variety of institutions including Defra, SEAC and breed societies. Similarly, the biosocial collective identified through FAnGR comprises all livestock in the UK (categorised as species, breed and strain), their 'genetic resources', humans (as, inter alia, breeders, policymakers, scientists) and institutions (eg, breed societies, species organisations, governments). The targeted populations identified by NSP and FAnGR can be seen to both pre-exist, but also be reproduced through, these interventions (eg, breed is a long-standing and accepted way of understanding livestock). In contrast, the biosocial collectives appear to be rather more emergent and contingent, brought into being through the policy interventions and potentially associated with new political activities.

The populations that are the focus of the strategies for intervention in the AEBC and FAWC reports are, like those of the NSP and FAnGR, multiple and broadly conceived. In the case of the former, it is 'animals' in the UK that is the primary population of interest, categorised as farm animals, companion and sporting animals and those involved in xenotransplantation. Individual (cf. populations of) animals outside the UK are mentioned (eg, the production of high-value farm animals through cloning in Australia and the US), as are flows of genetic material and genetically engineered animals across national boundaries. Given the AEBC's remit of national regulation it is inevitable that a national population of 'animals' - broadly conceived should be the focus of its strategies for intervention. The more specialist concerns of FAWC may explain the focus of its strategies for intervention on populations similar to those identified in the NSP and FAnGR. Here, then, population is defined primarily in genetic terms, as farm animal 'genotypes' produced through conventional breeding strategies and 'new' breeding technologies. Alongside this, species of farm animals, breeds, and also types of animal such as dairy cows and broiler chickens are further populations of interest. As with the AEBC, international animal populations are recognised, eg, through reference to the international effort involved in animal genetic engineering and of flows of genetic material and genetically engineered animals across national boundaries. However, the ultimate focus of FAWC's primary strategy of intervention is national farm animal genotypes, a scale of intervention in animal 
populations that is subsequently rejected by the Government as redundant in the face of the international nature of farm animal breeding.

Suggestions of biosocial collectivities are apparent in the AEBC and FAWC reports. In broad terms, this is evident in the AEBC's relational vision. When discussing farm animals (and how biotechnology may impact them) the report emphasises that these should not need to be viewed in isolation, but in relation to other animals. This reinforces its assertion that biotechnology has to be understood and approached in relation to other livestock farming practices (something that FAWC also advocates) and that both need to be situated in the context of society's attitudes to animals more broadly. This highly relational vision is one that is likely to reflect the social scientific expertise on the AEBC and the social scientific research it commissioned. ${ }^{53}$ More specifically, and evident in both the AEBC and FAWC reports, is their combined calls for enhanced monitoring and surveillance of farm animal populations that are the subject of breeding strategies and technologies. In both cases the imagined biosocial collective comprises farm animals (as breeds, species, types and genotypes), individual humans such as farmers, breeders and veterinary surgeons, biotechnological and other breeding interventions (some of which are not yet commercially available), and a variety of institutions including the government (its various advisory bodies - existing and new - and departments), breeding companies and breed societies. The public may be seen to comprise an additional member of this biosocial collective in the vision of the AEBC where greater public engagement with animal genetic biotechnology is advocated and reflects a wider trend towards greater public consultation and engagement in decision-making.

In summary, analysis of the four policies provide evidence for at least two of Rabinow and Rose's three dimensions of biopower in the context of livestock breeding through genetic techniques, albeit variably expressed. The concluding part of the paper considers the third dimension and makes suggestions regarding the need for further conceptual and empirical research in this domain.

\section{Conclusion}

Rabinow and Rose summarise their understanding of what is necessary to biopower as follows:
...knowledge of vital life processes, power relations which take humans as living beings as their object, and the modes of subjectification through which subjects work on themselves qua living beings...

We conclude by assessing the relevance of such an approach to the study of livestock animals and their breeding through genetic techniques, explored through the medium of policy, and by raising some questions associated with thinking about humanlivestock relations through the lens of biopower.

The first two of Rabinow and Rose's elements seem strongly applicable to the case of agricultural animals and genetic interventions in their lives. The emergence of 'truth discourses' which locate vital life processes at the level of genetic material has 
become increasingly evident in livestock breeding, ${ }^{55}$ just as they have in the context of medical interventions in human life. ${ }^{56}$ Scientific and political authorities increasingly considered able to speak that truth have become prominent in agriculture and livestock breeding. Similarly, the policy and consultation documents examined in this paper are evidence of power relations involving strategies for intervening in the lives and existences of groups of living beings - although here it is livestock animals rather than humans which are the immediate focus of such interventions. What emerges from our assessment of the four policy issues is that the notion of what constitutes the livestock population to be intervened in is far from straightforward. Populations defined at different scales (eg, national or farm scale), and of different types (eg, species, breed or genotype), are identified and co-exist within individual documents. As such, rather than policies simply targeting pre-existing populations, multiple and entangled populations are constituted through the truth discourses and interventions associated with policy documents. Further, differently circumscribed populations draw heterogeneous others (eg, humans, genetic material, or organisations) into relational associations with them. Definitions of population as a result form the basis of the particular heterogeneous bio-social collectivities which are intervened in. Policy interventions which constitute and engage with such collectivities thus effectively extend the purview of biopower to include animals (inter alia) in their relationships with humans.

The third of Rabinow and Rose's elements is rather more problematic. Animals' subjectivity is, to an extent, addressed by those aspects of the policy interventions which are concerned with issues of 'animal welfare' in agriculture. Yet throughout, it is difficult to comprehend how livestock can be understood as 'working on themselves' in the way Rabinow and Rose, and Foucault, imply, and yet this is absolutely crucial to the concept of biopower since the "process of producing 'docile' minds and bodies is not (indeed cannot be, on grounds of cost) confined to state institutions and discourses watching over, regulating and controlling people's thoughts and behaviour. The basic idea of biopower is to produce self-regulating subjects". ${ }^{57}$ In other words, once (human) bodies and minds have been shaped in particular ways by truth discourses then the individual 'takes over', to regulate themselves so that they continue to function in healthy ways and as 'good subjects'. The most economical form of surveillance, as Danaher et $\mathrm{al}^{58}$ argue, is selfsurveillance. It is this dimension of biopower that is a stumbling block to the acceptance of biopower, as Rabinow and Rose define it, in relation to human interventions in the lives of livestock animals.

In response, we suggest that an extended notion of the relations which constitute subjectivity might offer a way to explore how biopower is articulated through humananimal relationships. Specifically, and in relation to the four policy interventions examined here, we argue that 'geneticised' truth discourses and interventions are associated with the production of modes of human subjectivity which have the effect that (some) humans work, not only on themselves, but on the bodies and experiences of livestock animals as other living beings. This is not to downplay the importance of the animals themselves. Instead, the theoretical challenge is to explore how, within particular modes of biopower, heterogeneous relationships between humans and nonhumans are structured and played out, recognising the significance of both the 
bodily materiality and the subjectivity of humans and animals in relation to particular sets of power relations. As such, by relocating and distributing the focus of biopower, a more relational conception of biopower in which individuals work on nonhuman others alongside their work on themselves, might begin to be formulated. Thus, for example, much of the intervention suggested or required by the policy documents we have examined demands the enrolment of livestock breeders and farmers into practices of surveillance and monitoring of livestock animals, and into bureaucratic processes of record keeping, reporting and communication, all of which are associated with the exercise of biopower in relation to animal lives and bodies. In arguing for this more distributed sense of biopower and biosocial collectivities, we begin to look towards the poststructuralist perspectives offered by, for instance, science and technology studies and actor-network theory, ${ }^{59}$ in order to develop understandings of biopower (and, indeed, other modes of power) which more adequately account for trans-species relationships. At the same time, we argue that detailed empirical work within networks of breeders, scientists and others is demanded in order to fully examine the modalities and complexities of biopower as they are expressed and performed in particular circumstances. ${ }^{60}$ Thus, our initial assessment of the usefulness of biopower as an analytical concept sets an agenda for further theoretical and empirical work which will greatly enhance our understanding of the implications of genetic techniques for livestock agriculture.

\footnotetext{
${ }^{1}$ Lewis Holloway, Department of Geography, University of Hull, UK 1.holloway@hull.ac.uk; Carol Morris, School of Geography, University of Nottingham, UK Carol.Morris@nottingham.ac.uk.

${ }^{2} \mathrm{We}$ acknowledge that there is an important distinction between genetics and genomics. However, for the sake of clarity and ease of reading the term 'genetic' is used in this paper to include both 'classical' quantitative genetics and 'modern' genomics as these have developed in the context of breeding livestock. G. Bulfield. Farm animal biotechnology. Trends in Biotechnology 2000; 8: 10-13. ${ }^{3}$ Bulfield, op. cit. note 2. A. Archibald and C. Haley. What can the genetics revolution offer the meat industry? Outlook on Agriculture 2003; 32: 219-226. S. Bishop and J.A. Woolliams. Genetic approaches and technologies for improving the sustainability of livestock production. Journal of the Science of Food and Agriculture 2004; 84: 911-919. D. Elstein, J. Comis and A. Flores. Unraveling the genome of the honey bee, pig, cow and chicken: an agency effort to sequence genomes. Agricultural Research 2005; January: 4-9. E.A. Maga. Genetically engineered livestock: closer than we think? Trends in Biotechnology 2005; 23: 533-535.

${ }^{4}$ Archibald and Haley op. cit, note 3.

${ }^{5}$ See, for example, the work of Sarah Franklin on new forms of 'biocapital' and 'bioprospecting' related to genetic technologies. S. Franklin. Mapping Biocapital: new frontiers of bioprospecting. Cultural Geographies 2006; 13: 301-304. S. Franklin. Sheepwatching. Anthropology Today 2001; 17 : 3-9. S. Franklin. Dolly: a new form of transgenic breedwealth. Environmental Values 1997; 6: $427-$ 437.

${ }^{6}$ M. Foucault. 1990. The History of Sexuality, Volume 1: An Introduction. Penguin. Harmondsworth. M. Foucault. 2004. Society Must Be Defended. Penguin. London.

${ }^{7}$ P. Rabinow and N. Rose. 2003. Thoughts on the Concept of Biopower Today http://www.molsci.org/files/Rose Rabinow_Biopower Today.pdf (accessed 01.02.2005).

${ }^{8}$ Defra. 2003. National Scrapie Plan for Great Britain: NSP Programme Brief. London. Defra.

${ }^{9}$ Defra. 2006. UK National Action Plan on Farm Animal Genetic Resources. London. Defra.

${ }^{10}$ Agriculture and Environment Biotechnology Commission. 2002. Animals and Biotechnology: a Report by the AEBC. London. AEBC.

${ }^{11}$ Farm Animal Welfare Council. 2004. FAWC Report on the Welfare Implications of Animal Breeding and Breeding Technologies in Commercial Agriculture. London. FAWC.

${ }^{12}$ MAFF. 1994. Report of the Committee to Consider the Ethical Implications of Emerging Technologies in the Breeding of Farm Animals (the 'Banner Report'). London. HMSO. Farm Animal
} 
Welfare Council.1998. Report on the Implications of Cloning for the Welfare of Farmed Livestock. London. FAWC. AEBC, op. cit. note 10. Royal Society. 2001. The Use of Genetically Modified Animals. London. The Royal Society. Animal Procedures Committee. 2001. Report on Biotechnology. London. The Animal Procedures Committee.

${ }^{13}$ Rabinow and Rose, op. cit. note 7.

${ }^{14}$ Foucault, op. cit. note 6.

${ }^{15}$ Rabinow and Rose, op. cit. note 7. B. Braun. Biopolitics and the Molecularisation of Life. Cultural Geographies 2007; 14: 6-28.

${ }^{16}$ Foucault. 1990, op. cit. note 6, p.139.

${ }^{17}$ Braun, op. cit. note 15. p.9.

${ }^{18}$ Braun, op. cit. note 15. p.9.

${ }^{19}$ M. Foucault. 1978 [2001]. The politics of health in the $18^{\text {th }}$ century. In Essential Works of Foucault, 1954-1984: Power (Vol. 3). J. D. Faubion ed. London. Penguin pp. 90-105. E. Yoxen. 1982. Giving Life a New Meaning: The Rise of the Molecular Biology Establishment. In Scientific establishment and heirarchies: sociology of the sciences, vol. VI. N. Elias, H. Martins and R. Whitley, eds.: 123-143. ${ }^{20}$ J. Marks. Biopolitics. Theory, Culture and Society 2006; 23: 333-335. p.333.

${ }^{21}$ Braun, op. cit. note 15 . p.8-9.

${ }^{22}$ S. Legg. Foucault's Population Geographies: Classifications, Biopolitics and Governmental Spaces. Population, Space and Place 2005; 11: 137-156.

${ }^{23}$ Rabinow and Rose, op. cit. note 7.

${ }^{24}$ Marks, op. cit. note 20.

${ }^{25}$ Rabinow and Rose, op. cit. note 7. p.3.

${ }^{26}$ Ibid, p.23

${ }^{27}$ Ibid, p. 2

${ }^{28}$ Ibid, p. 3

${ }^{29}$ Ibid, p.23

${ }^{30}$ Marks, op. cit. note 20. p.333.

${ }^{31}$ S. Legg. Governmentality, Congestion and Calculation in Colonial Delhi. Social and Cultural Geography 2006; 7: 709-729.

${ }^{32}$ E. Gilbert. Leaky Borders and Solid Citizens: Governing Security, Prosperity and Quality of Life in a North American Partnership. Antipode 2007; 39: 77-98.

${ }^{33}$ J. Novek. Pigs and People: Sociological Perspectives on the Discipline of Nonhuman Animals in Intensive Confinement. Society and Animals 2005; 13: 221-244. A. Williams. Disciplining Animals: Sentience, Production and Critique. International Journal of Sociology and Social Policy 2004; $24: 45$ 57. C. Palmer. 'Taming the Wild Profusion of Existing Things'? A Study of Foucault, Power and Human/animal Relationships. Environmental Ethics 2001; 23: 339-358. L. Holloway. Subjecting Cows to Robots: Farming Technologies and the Making of Animal Subjects. Environment and Planning D: Society and Space 2007; 25.

${ }^{34}$ I. Convery, C.Bailey, M. Mort, J. Baxter J. Death in the Wrong Place? Emotional Geographies of the UK 2001 Foot and Mouth Disease Epidemic. Journal of Rural Studies 2005; 21: 99-109.

${ }^{35}$ H. Ritvo. 1987 The Animal Estate: The English and Other Creatures in the Victorian Age. Cambridge MA: Harvard University Press. K. Anderson. A Walk on the Wild Side: A Critical Geography of Domestication. Progress in Human Geography 1997; 21: 463-485. L. Holloway. Aesthetics, Genetics and Evaluating Animal Bodies: Locating and Displacing Cattle on Show and in Figures. Environment and Planning D: Society and Space 2005; 23: 883-902. L. Holloway and C. Morris. Animal Bodies and Genes: Contested Expertise in the Fields of Breeding for Beef and Disease Eradication. Paper presented at the session 'Spaces of knowledge, communities of knowing', RGS-IBG annual conference, London, September 2005.

${ }^{36}$ The definition of breed is problematic. Most simply, for authors such as Clutton-Brock, it refers to a group of animals which can be distinguished from other groups on the basis of appearance, so that when members of a group breed their offspring reproduce their particular 'type'. However, we find this type of definition quite limited, and for our purposes it might be more helpful to see breed as a more complex set of relationships, a bio-social collectivity which includes breeders and breed societies, and discourses and practices of livestock breeding, along with the animals themselves. J. Clutton-Brock. 1994. The Unnatural World. In Animals and Human Society: Changing Perspectives. A. Manning and J. Serpell, eds. London. Routledge pp. 23-35. 


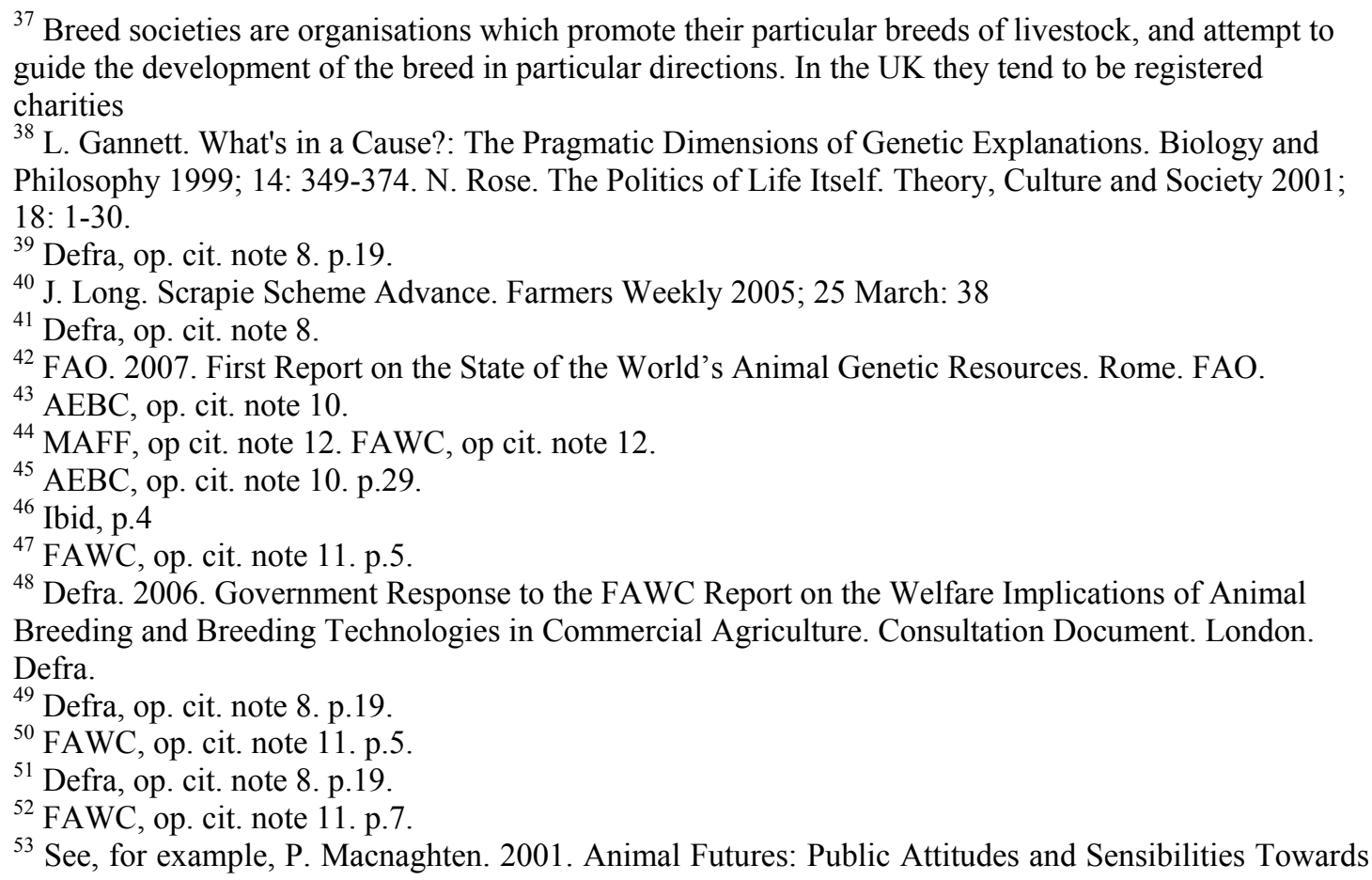
Animals and Biotechnology in Contemporary Britain. A Report by the Institute for Environment, Philosophy and Public Policy for the Agricultural and Environmental Biotechnology Commission.

${ }^{54}$ FAWC, op. cit. note 11. p.7.

${ }^{55}$ See also C. Grasseni. Designer Cows: The Practice of Cattle Breeding Between Skill and Standardisation. Society and Animals 2005; 13: 33-50. Holloway, op. cit. note 33.

${ }^{56}$ see, for example, E. Yoxen. 1982. Giving Life a New Meaning: The Rise of the Molecular Biology Establishment. In Scientific establishment and hierarchies: sociology of the sciences, vol.VI. N. Elias, H. Martins and R. Whitley, eds. Doerdrecht: D. Reidel Publishing Co.: 123-143. L. Kay. 1993. The Molecular Vision of Life: Caltech, the Rockefeller Foundation and the Rise of the New Biology. Oxford. Oxford University Press. E. Keller. 2000. The Century of the Gene. Cambridge, Mass. Harvard University Press. D. Haraway. 1997.

Modest_Witness@Second_Millennium.FemaleMan@_Meets_OncoMouse ${ }^{\mathrm{TM}}$ : Feminism and Technoscience. London. Routledge.

${ }^{57}$ G. Danaher, T. Schirato and J. Webb. 2000. Understanding Foucault. London, Sage. ${ }^{58}$ Ibid

${ }^{59}$ Eg, B. Latour. 1999. Pandora's Hope: Essays on the Reality of Science Studies. London. Harvard University Press. B. Latour. 2005. Re-assembling the Social: An Introduction to Actor-Network Theory. Oxford. Oxford University Press. J. Law and A. Mol, eds. 2002. Complexities: Social Studies of Knowledge Practices. London. Duke University Press.

${ }^{60}$ Such empirical research is at the heart of our forthcoming research project, 'Genetics, genomics and genetic modification in agriculture: emerging knowledge-practices in making and managing farm livestock' funded by the UK Economic and Social Research Council (ref. RES-062-23-0642). 